\title{
The effect of sexually transmitted co-infections on HIV viral load amongst individuals on antiretroviral therapy: a systematic review and meta-analysis
}

\author{
David Champredon ${ }^{1 *}$, Steven E Bellan², Wim Delva ${ }^{3,4}$, Spencer Hunt ${ }^{1}$, Chyun-Fung Shi ${ }^{1}$, Marek Smieja ${ }^{1}$ \\ and Jonathan Dushoff ${ }^{1}$
}

\begin{abstract}
Background: Antiretroviral therapy (ART) markedly reduces HIV transmission, and testing and treatment programs have been advocated as a method for decreasing transmission at the population level. Little is known, however, about the extent to which sexually transmitted infections (STIS), which increase the HIV infectiousness of untreated individuals, may decrease the effectiveness of treatment as prevention.
\end{abstract}

Methods: We searched major bibliographic databases to August $12^{\text {th }}, 2014$ and identified studies reporting differences in HIV transmission rate or in viral load between individuals on ART who either were or were not co-infected with another STI. We used hierarchical Bayesian models to estimate viral load differences between individuals with and without STI co-infections.

Results: The search strategy retrieved 1630 unique citations of which 14 studies (reporting on 4607 HIV viral load measurements from 2835 unique individuals) met the inclusion criteria. We did not find any suitable studies that estimated transmission rates directly in both groups. Our meta-analysis of HIV viral load measurements among treated individuals did not find a statistically significant effect of STI co-infection; viral loads were, on average, $0.11 \log 10(95 \% \mathrm{Cl}-0.62$ to 0.83 ) higher among co-infected versus non-co-infected individuals.

Conclusions: Direct evidence about the effects of STI co-infection on transmission from individuals on ART is very limited. Available data suggests that the average effect of STI co-infection on HIV viral load in individuals on ART is less than $1 \log 10$ difference, and thus unlikely to decrease the effectiveness of treatment as prevention. However, there is not enough data to rule out the possibility that particular STIs pose a larger threat.

\section{Background}

A large body of evidence suggests that antiretroviral therapy (ART), particularly with newer treatment regimens, markedly reduces the risk of sexual transmission of HIV. Recent systematic reviews have estimated that ART causes a more than ten-fold reduction in the incidence rate within discordant couples, to less than 0.5 per 100 person-years [1-6].

These sharp reductions have inspired the idea of antiretroviral treatment as prevention-aggressive programs to identify and treat HIV-positive individuals could

\footnotetext{
* Correspondence: david.champredon@gmail.com

${ }^{1}$ McMaster University, Hamilton, ON, Canada

Full list of author information is available at the end of the article
}

substantially reduce HIV incidence at the population level, by reducing the infectiousness of HIV-infected individuals $[5,7]$. However, increased infectiousness when treated individuals are co-infected with one or more other sexually transmitted infections (STIs) could potentially undercut the effectiveness of treatment as prevention programs. Concern with the effects of co-infection on HIV transmission is exemplified in the 2008 "Swiss Statement," which argues that HIV sexual transmission risk is of no concern within stable discordant relationships in which: an HIV-positive partner is adhering to treatment under the care of a physician; the viral load has been suppressed for at least six months; and no other STIs are infecting the HIV-positive partner [8]. 
Although the biological mechanisms underlying this increased risk are not fully understood, many STIs have been associated with higher risks of both HIV acquisition and sexual transmission [9-15]. Increased HIV transmission may be underpinned by higher HIV viral load resulting from larger concentration of HIV-infected immune cells in genital secretions induced by an inflammatory response and/or additional pathways caused by genital ulcers [16]. Similarly, inflammatory STIs, by recruiting immune cells, may provide additional targets for HIV virions, increasing HIV acquisition risk. Ulcerative STIs may present additional entry points for HIV infection [15].

Studies of HIV-STI interactions have been conducted mostly on individuals not receiving ART. Less is known about the impact of STI co-infections on HIV shedding from treated individuals. STI prevalence is high among HIV-infected individuals [17] and the proportion of these individuals on ART is quickly rising [18]. Thus, any potential increased HIV infectiousness due to STI co-infections among treated individuals could have important epidemiological consequences as treatment as prevention becomes more widespread.

Disentangling the many interacting factors at play is challenging: many STIs are suspected of affecting HIV shedding [9] and it remains unclear whether how these effects interact in people with more than one such infection; the viral load response to ART is regimen- and gender-specific [19]; numerous (not necessarily consistent) methods are used to sample and quantify HIV viral load [20, 21]; viral load measurements can vary between anatomical sites within an infected individual [22]; and HIV viral loads exhibit substantial temporal variation [23]. When considering transmission events in discordant couples, isolating the effect of STI co-infections is challenging because concomitance of STI infections in both partners (that could affect both HIV susceptibility and infectiousness) and HIV transmission are often not practical to ascertain.

Here, we conduct a systematic review and meta-analysis of the available evidence to assess whether STI coinfections affect the risk of HIV transmission from individuals on ART. We searched for studies that estimated transmission directly, and also for studies that measured viral load, which we intended to use as a proxy for transmission if the direct evidence was insufficient.

\section{Methods}

This systematic review and meta-analysis followed the guidelines from the PRISMA statement [24] (see Additional file 1). A protocol was prospectively registered in the PROSPERO database (see Additional file 2). Published peer-reviewed observational studies and randomized controlled trials were considered for inclusion. We included studies of sexually active HIV-infected participants on ART that were further classified into two subgroups: participants whose only known STI was HIV (the "mono-infected group") and those with HIV and co-infected with another STI (the "co-infected group"). Studies were eligible for inclusion if they measured HIV viral loads among HIV-infected participants, or if they observed at least monthly HIV transmission events and STI infection status in discordant couples. An individual was considered co-infected only if the STI was laboratory confirmed. Individuals with ongoing treatment for the coinfecting STI were not included.

We searched for all relevant studies in Medline (Ovid), EMBASE (Ovid), PubMed, CINAHL and the Cochrane Library from inception to August $12^{\text {th }}, 2014$. Subject headings and text words associated with the risk of HIV sexual transmission, ART and STIs were included in the search strategies. We included STIs commonly discussed in the context of HIV transmission: Chlamydia trachomatis, chancroid (H. ducreyi), any type of Human Papilloma Virus, Herpes Simplex Virus 2, Neisseria gonorrhoeae, syphilis (T. pallidum) and Trichomoniasis (T. vaginalis). We also included bacterial vaginosis and candidal vaginitis, although these are not known to result directly from sexual transmission, and urethritis, which can be associated with more than one STI. The search did not impose any language or geographical restrictions on studies. The STI positivity definitions are given in Additional file 3 and full search strategies in Additional file 4.

All retrieved abstracts were read by three authors (DC, $\mathrm{CS}$ and $\mathrm{SH}$ ). Eligibility assessment was performed independently by two authors for each abstract, using pre-defined guidelines. Disagreement between authors was resolved by consensus after discussion. Data from eligible studies were extracted independently by two authors (DC and SH).

We sought to assess how two primary outcomes of interest, HIV viral loads and HIV transmission rates within discordant couples, varied between HIV-infected participants on ART with and without STI co-infections. We sought additional data to assess potential sources of bias within and between studies including STI diagnostic methods; anatomical sites sampled for HIV viral load measurements; HIV assays; interval between STI co-infection diagnosis and HIV viral load measurement; ART regimen, treatment length and adherence; study design; HIV-infected participant age, gender, and sexual orientation; and, for serodiscordant couple studies, concomitance of STI co-infection in HIV-uninfected partner and HIV genetic linkage following secondary partner seroconversion. Within studies, we excluded individuals not explicitly known to be on ART and, when this information was available, those who had been on ART for less than 30 days. We probed study quality by summarizing variables and methods (Tables 1 and 2), and with forest and funnel plots (Figs. 3 and 4).

Planned measures of effect were: the difference in $\log 10$ HIV viral load between the mono- and co-infected groups, 
Table 1 Summary table of studies included in the meta-analysis

\begin{tabular}{|c|c|c|c|c|c|c|c|c|c|c|c|}
\hline Study & Study objective & Country & Population & $\begin{array}{l}\text { Coverage } \\
\text { period }\end{array}$ & Study design & STI & $\begin{array}{l}\text { STI assessment } \\
\text { method }\end{array}$ & $\begin{array}{l}\text { Number of } \\
\text { participants }\end{array}$ & $\begin{array}{l}\text { Individuals } \\
\text { included in } \\
\text { meta-analysis }\end{array}$ & $\begin{array}{l}\text { HIV viral load } \\
\text { measure }\end{array}$ & $\begin{array}{l}\text { HIV VL } \\
\text { anatimical } \\
\text { site }\end{array}$ \\
\hline Adolf 2012 [31] & $\begin{array}{l}\text { Prevalence and risk } \\
\text { factors for syphilis } \\
\text { among HIV+ }\end{array}$ & Brazil & $\begin{array}{l}\text { Females and } \\
\text { males; STI/HIV } \\
\text { clinic patients- } \\
\text { SoBrHIV cohort }\end{array}$ & $1991-2008$ & Case-control & $T p$ & VDRL, FTA & 1012 & 759 & Not reported & $\begin{array}{l}\text { Blood } \\
\text { plasma }\end{array}$ \\
\hline \multirow[t]{5}{*}{ Anderson 2008 [32] } & \multirow{5}{*}{$\begin{array}{l}\text { Association between } \\
\text { presence of } \\
\text { inflammatory }\end{array}$} & \multirow[t]{5}{*}{ USA } & \multirow{5}{*}{$\begin{array}{l}\text { Females; STI/HIV } \\
\text { clinic patients }\end{array}$} & \multirow{5}{*}{$\begin{array}{l}\text { Not } \\
\text { reported }\end{array}$} & \multirow{5}{*}{$\begin{array}{l}\text { Prospective } \\
\text { cohort }\end{array}$} & \multirow{5}{*}{$\begin{array}{l}\text { Bv Ct Cv } \\
\text { Ng Tp Tv }\end{array}$} & Bv: Amsel & \multirow[t]{5}{*}{97} & \multirow[t]{5}{*}{41} & \multirow[t]{5}{*}{ RNA } & \multirow{5}{*}{$\begin{array}{l}\text { Blood and } \\
\text { CVL }\end{array}$} \\
\hline & & & & & & & Ct, Ng: culture & & & & \\
\hline & & & & & & & $\begin{array}{l}\text { Cv: visual } \\
\text { exam }\end{array}$ & & & & \\
\hline & & & & & & & Tv: wet mount & & & & \\
\hline & & & & & & & $T p: R P R$ & & & & \\
\hline \multirow[t]{3}{*}{ Conley 2010 [33] } & \multirow{3}{*}{$\begin{array}{l}\text { Prevalence and risk } \\
\text { factors for abnormal } \\
\text { anal cytology among } \\
\text { HIV+ }\end{array}$} & \multirow[t]{3}{*}{ USA } & \multirow{3}{*}{$\begin{array}{l}\text { Females and } \\
\text { males; STI/HIV } \\
\text { clinic patients - } \\
\text { SUN study }\end{array}$} & \multirow[t]{3}{*}{ 2004-2006 } & \multirow[t]{3}{*}{$\begin{array}{l}\text { Prospective } \\
\text { cohort }\end{array}$} & \multirow{3}{*}{$\begin{array}{l}\text { Ct HPV } \\
\text { HSV Ng } \\
\text { Tp TV }\end{array}$} & $\begin{array}{l}\text { HPV, Ng, Ct: } \\
\text { NAAT, cytological }\end{array}$ & \multirow[t]{3}{*}{621} & \multirow[t]{3}{*}{147} & \multirow[t]{3}{*}{ RNA } & \multirow[t]{3}{*}{$\begin{array}{l}\text { Not } \\
\text { reported }\end{array}$} \\
\hline & & & & & & & TV: NAAT & & & & \\
\hline & & & & & & & HSV2: serology & & & & \\
\hline \multirow[t]{3}{*}{ Chan 2008 [12] } & \multirow{3}{*}{$\begin{array}{l}\text { Correlation between } \\
\text { HIV VL in blood and } \\
\text { semen among men } \\
\text { both ART naive and } \\
\text { experienced }\end{array}$} & \multirow[t]{3}{*}{ Australia } & \multirow{3}{*}{$\begin{array}{l}\text { Males; STI/HIV } \\
\text { clinic patients }\end{array}$} & \multirow[t]{3}{*}{$2003-2006$} & \multirow{3}{*}{$\begin{array}{l}\text { Prospective } \\
\text { cohort }\end{array}$} & \multirow[t]{3}{*}{$\mathrm{Ct} \mathrm{Ng} \mathrm{Tp}$} & Ct: NAAT & \multirow[t]{3}{*}{119} & \multirow[t]{3}{*}{81} & RNA & Blood and \\
\hline & & & & & & & Ng: culture & & & & \\
\hline & & & & & & & Tp: Fabs + RPR & & & & \\
\hline Cu-Uvin 2001 [26] & Impact of genital tract & USA & Females; STI/HIV & Not & Prospective & Bv Cv Tv & Bv: Amsel & 108 & 61 & RNA & Blood and \\
\hline & $\begin{array}{l}\text { Infections on HIV } \\
\text { cervicovaginal shedding }\end{array}$ & & & reported & cohort & & Cv, Tv: culture & & & & \\
\hline Graham 2011 [34] & Impact of genital & Kenya & Females; STI/HIV & $2004-2008$ & Prospective & $\mathrm{Bv} C t \mathrm{Cv}$ & Tv: wet mount & 145 & 37 & RNA & Cervix and \\
\hline & $\begin{array}{l}\text { ulcerations on HIV } \\
\text { genital shedding }\end{array}$ & & & & & $\begin{array}{l}\text { Hd Ng Ip } \\
\text { Tv }\end{array}$ & Bv: Nugent & & & & vagina \\
\hline & & & & & & & Cv: not reported & & & & \\
\hline & & & & & & & $\begin{array}{l}\text { Ng: culture + } \\
\text { NAAT }\end{array}$ & & & & \\
\hline & & & & & & & Ct: NAAT & & & & \\
\hline & & & & & & & Hd: culture & & & & \\
\hline & & & & & & & Tp: serology & & & & \\
\hline $\begin{array}{l}\text { Jarzebowski } 2012 \\
{[35]}\end{array}$ & $\begin{array}{l}\text { Impact of syphilis on } \\
\text { CD4 and HIV VL }\end{array}$ & France & $\begin{array}{l}\text { Males; MSM- } \\
\text { FHDH cohort }\end{array}$ & 1998-2006 & Case-control & $T p$ & Not reported & 1515 & 1271 & RNA & $\begin{array}{l}\text { Blood } \\
\text { plasma }\end{array}$ \\
\hline Kofoed 2006 [36] & $\begin{array}{l}\text { Impact of Syphilis } \\
\text { infection on CD4, } \\
\text { HIV VL and response } \\
\text { after anti-treponemal } \\
\text { treatment }\end{array}$ & Denmark & Males; MSM & 2003-2004 & $\begin{array}{l}\text { Prospective } \\
\text { experimental }\end{array}$ & Tp & $\begin{array}{l}\text { Dark field, } \\
\text { serology }\end{array}$ & 38 & 34 & RNA & $\begin{array}{l}\text { Blood } \\
\text { plasma }\end{array}$ \\
\hline
\end{tabular}


Table 1 Summary table of studies included in the meta-analysis (Continued)

\begin{tabular}{|c|c|c|c|c|c|c|c|c|c|c|c|}
\hline Madeddu 2014 [41] & $\begin{array}{l}\text { HPV screening should } \\
\text { be done even on } \\
\text { HIV-positive women } \\
\text { on ART }\end{array}$ & Italy & $\begin{array}{l}\text { Females; STI/HIV } \\
\text { clinic patients }\end{array}$ & $2008-2009$ & $\begin{array}{l}\text { Prospective } \\
\text { cohort }\end{array}$ & HPV & NAAT & 57 & 52 & RNA & $\begin{array}{l}\text { Blood } \\
\text { plasma }\end{array}$ \\
\hline \multirow[t]{2}{*}{ Politch 2012 [37] } & \multirow{2}{*}{$\begin{array}{l}\text { Prevalence of seminal } \\
\text { HIV shedding among } \\
\text { MSM on ART }\end{array}$} & \multirow[t]{2}{*}{ USA } & \multirow[t]{2}{*}{ Males; MSM } & \multirow{2}{*}{$\begin{array}{l}\text { Not } \\
\text { reported }\end{array}$} & \multirow{2}{*}{$\begin{array}{l}\text { Prospective } \\
\text { cohort }\end{array}$} & \multirow{2}{*}{$\begin{array}{l}\text { Ct HSV Ng } \\
\text { Tp NGU }\end{array}$} & HSV: serology & \multirow[t]{2}{*}{101} & \multirow[t]{2}{*}{96} & \multirow{2}{*}{$\begin{array}{l}\text { DNA and } \\
\text { RNA free and } \\
\text { RNA assoc }\end{array}$} & \multirow[t]{2}{*}{ Semen } \\
\hline & & & & & & & $\begin{array}{l}\mathrm{Ct}, \mathrm{Ng}, \mathrm{Tp} \text { : not } \\
\text { reported }\end{array}$ & & & & \\
\hline \multirow[t]{2}{*}{ Sadiq 2002 [38] } & \multirow{2}{*}{$\begin{array}{l}\text { Effect of urethritis on } \\
\text { seminal HIV VL for } \\
\text { patients on ART }\end{array}$} & \multirow[t]{2}{*}{ UK } & \multirow[t]{2}{*}{ Males; MSM } & \multirow[t]{2}{*}{ 1998-2000 } & \multirow{2}{*}{$\begin{array}{l}\text { Prospective } \\
\text { cohort }\end{array}$} & \multirow{2}{*}{$\begin{array}{l}\mathrm{Ct} \mathrm{Ng} \\
\mathrm{NGU}\end{array}$} & Ng: culture & \multirow[t]{2}{*}{40} & \multirow[t]{2}{*}{39} & \multirow{2}{*}{$\begin{array}{l}\text { RNA and } \\
\text { DNA }\end{array}$} & \multirow{2}{*}{$\begin{array}{l}\text { Blood and } \\
\text { semen }\end{array}$} \\
\hline & & & & & & & Ct: NAAT & & & & \\
\hline \multirow[t]{5}{*}{ Sha 2005 [39] } & \multirow{5}{*}{$\begin{array}{l}\text { Association of Bv and } \\
\text { Bv-associated bacteria } \\
\text { with HIV genital VL }\end{array}$} & \multirow[t]{5}{*}{ USA } & \multirow[t]{5}{*}{$\begin{array}{l}\text { Females; STI/HIV } \\
\text { clinic patients }\end{array}$} & \multirow[t]{5}{*}{ 1994-1997 } & \multirow[t]{5}{*}{$\begin{array}{l}\text { Prospective } \\
\text { cohort }\end{array}$} & \multirow{5}{*}{$\begin{array}{l}\text { Bv Ct Cv } \\
\text { HPV HSV } \\
\text { Ng Tp TV }\end{array}$} & $\begin{array}{l}\text { Bv: Amsel + } \\
\text { Nugent }\end{array}$ & \multirow[t]{5}{*}{362} & \multirow[t]{5}{*}{107} & \multirow[t]{5}{*}{ RNA } & \multirow[t]{5}{*}{$\begin{array}{l}\text { Blood and } \\
\text { CVL }\end{array}$} \\
\hline & & & & & & & $\begin{array}{l}\text { Tp: symptoms + } \\
\text { DFA }\end{array}$ & & & & \\
\hline & & & & & & & $\begin{array}{l}\text { Ct, Ng: culture + } \\
\text { pap }\end{array}$ & & & & \\
\hline & & & & & & & $\begin{array}{l}\text { HSV: symptoms + } \\
\text { pap }\end{array}$ & & & & \\
\hline & & & & & & & HPV: NAAT & & & & \\
\hline \multirow[t]{4}{*}{ Sudenga 2012 [40] } & \multirow{4}{*}{$\begin{array}{l}\text { HSV2 epidemiology } \\
\text { in HIV+/at risk adolescents }\end{array}$} & USA & Females and & 1996-2000 & Case-control & $\mathrm{Bv} \mathrm{Ct} \mathrm{Hd}$ & HSV2: serology & 513 & 60 & RNA & Blood \\
\hline & & & $\begin{array}{l}\text { males; acolescent; } \\
\text { REACH cohort }\end{array}$ & & & Ng Tp TV & $\begin{array}{l}\mathrm{Ct}, \mathrm{Ng}, \mathrm{HPV} \text { : } \\
\text { NAAT }\end{array}$ & & & & 1 \\
\hline & & & & & & & $\begin{array}{l}\text { Bv: gram stain }+ \\
\text { clinical criteria }\end{array}$ & & & & \\
\hline & & & & & & & Tv: culture & & & & \\
\hline Winter 1999 [10] & $\begin{array}{l}\text { Impact of asymptomatic } \\
\text { urtethritis on HIV VL }\end{array}$ & UK & $\begin{array}{l}\text { Males; STI/HIV } \\
\text { clinic patients }\end{array}$ & $\begin{array}{l}\text { Not } \\
\text { reported }\end{array}$ & $\begin{array}{l}\text { Prospective } \\
\text { cohort }\end{array}$ & $\begin{array}{l}\mathrm{Ct} \mathrm{Ng} \\
\mathrm{NGU}\end{array}$ & $\begin{array}{l}\text { Ng: Gram stain, } \\
\text { culture }\end{array}$ & 94 & 53 & RNA cell free & $\begin{array}{l}\text { Blood and } \\
\text { semen }\end{array}$ \\
\hline & In & & & & & & Ct: NAAT & & & & \\
\hline
\end{tabular}

MSM: men who have sex with men
$B v$ Bacterial vaginosis, Cv Candidal vaginitis, Ct Chlamydia trachomatis, HPV, human papillomavirus, HSV human simplex virus type 2, Ng Neisseria gonorrhoeae, Tp Treponema pallidum, Tv Trichomonas vaginalis, Ur urethritis 
Table 2 Assessment of risk of bias within studies

\begin{tabular}{llll}
\hline Study & $\begin{array}{l}\text { Number of } \\
\text { STls tested }\end{array}$ & $\begin{array}{l}\text { Sampling site } \\
\text { for HIV }\end{array}$ & $\begin{array}{l}\text { ART adherence } \\
\text { reported }\end{array}$ \\
\hline Adolf 2012 [31] & 1 & Blood plasma & No \\
Anderson 2008 [32] & 6 & Blood and CVL & No \\
Conley 2010 [33] & 6 & Not reported & No \\
Chan 2008 [12] & 3 & Blood and semen & No \\
Cu-Uvin 2001 [26] & 3 & Blood and CVL & No \\
Graham 2011 [34] & 7 & Cervix and vagina & Yes \\
Jarzebowski 2012 [35] & 1 & Blood plasma & No \\
Kofoed 2006 [36] & 1 & Blood plasma & No \\
Madeddu 2014 [41] & 1 & Blood plasma & Yes \\
Politch 2012 [37] & 4 & Semen & No \\
Sadiq 2002 [38] & 2 & Blood and semen & No \\
Sha 2005 [39] & 8 & Blood and CVL & No \\
Sudenga 2012 [40] & 8 & Blood plasma & Yes \\
Winter 1999 [10] & 2 & Blood and semen & No \\
\hline
\end{tabular}

Studies reporting a large number of STIs tested, ART adherence and measuring HIV, VL viral load in genital secretions are less likely to bias estimates of the effect of STI co-infection on HIV transmission, CVL cervicovaginal lavage

for a given anatomical site and STI; and the relative HIV transmission rate between HIV-discordant couples with the infected partner belonging to the mono- versus coinfected group.

\section{Statistical analysis}

This review aims to gather all available evidence regarding the effect of STI on HIV infectiousness, whether this was the primary objective of a study or not. Hence,

Table 3 Number of HIV viral loads measurements included in the meta-analysis by STI co-infection and anatomical sites

\begin{tabular}{lllll}
\hline STI & Blood & Cervicovaginal & Semen & Total \\
\hline BV & 51 & 52 & $\mathrm{n} / \mathrm{a}$ & 103 \\
$\mathrm{Ct}$ & 9 & 0 & 9 & 18 \\
$\mathrm{CV}$ & 2 & 9 & $\mathrm{n} / \mathrm{a}$ & 11 \\
$\mathrm{HPV}$ & 260 & 76 & 0 & 336 \\
$\mathrm{HSV}$ & 86 & 0 & 60 & 146 \\
$\mathrm{Ng}$ & 9 & 2 & 9 & 20 \\
Tp & 656 & 2 & 2 & 660 \\
TV & 4 & 4 & 0 & 8 \\
Ur & 9 & $\mathrm{n} / \mathrm{a}$ & 12 & 21 \\
none & 2915 & 192 & 177 & 3284 \\
Total & 4001 & 337 & 269 & 4607 \\
\hline
\end{tabular}

Category "none" means there was no STI (other than HIV) co-infecting the patient $B v$ bacterial vaginosis, $\mathrm{Cv}$ candidal vaginitis, Ct Chlamydia trachomatis, HPV human papillomavirus, HSV human simplex virus type 2, Ng Neisseria gonorrhoeae, Tp Treponema pallidum, Tv Trichomonas vaginalis, Ur urethritis, n/a not applicable heterogeneity in study design is inevitable. For example, HIV viral load can be measured at different anatomical sites, with different sampling techniques, for patients with different STI co-infections. Estimating a single summary statistic for such heterogeneous effects is challenging. Adopting a classical approach to conduct the metaanalysis would make it difficult to fit all the studies into one modelling framework. For example it might be necessary to choose a threshold and dichotomize data from studies providing continuous HIV viral load in order to compare them with the ones providing dichotomous data only. Hierarchical Bayesian models offer a flexible framework to coherently incorporate heterogeneous variables that theoretically relate to a common effect while providing estimates of the variability at each conceptual level [25].

We therefore used a Bayesian hierarchical model to estimate-across heterogeneous studies-an overall effect of STI co-infection on HIV viral load, while also estimating how this effect differed depending on the anatomical site sampled for viral load measurements and on the specific STI co-infection. Similarly, we also estimated how the effect of STI co-infection differed between studies and included individual-level random effects for longitudinal studies. Studies where the only outcome available was dichotomous (HIV viral load above or below a stated threshold) $[10,12,26]$ were combined with studies that provided continuous outcomes by introducing latent variables [27]. We used uninformative priors for all effect sizes and their variances [28]. The details of the model and our prior choices are provided in Additional file 5. The model was developed in $\mathrm{R}$ version 3.0.2 [29] with package RSTAN version 2.2.0 [30]. Code is available upon request.

\section{Results}

\section{Systematic review}

Our database searches identified 2997 citations. In addition, 23 records were identified outside the database search (mostly via references cited in the publications retrieved from the database search). After duplicates were removed, 1630 records were assessed for eligibility (Fig. 1). We excluded 1277 records with abstracts that obviously did not meet our inclusion criteria, leaving 353 to be assessed with a full-text review. When studies appeared to have obtained but not published data relevant to our meta-analysis, we requested them from the original investigators. Of 73 investigators contacted for additional data, 21 responded and 10 provided data. This second screening identified 14 studies with sufficient information to be included in the meta-analysis [10, 12, 26, 31-41]. All studies included in our meta-analysis were approved by an ethics committee.

Table 1 summarizes the main characteristics of each eligible study. No studies involving discordant couples 


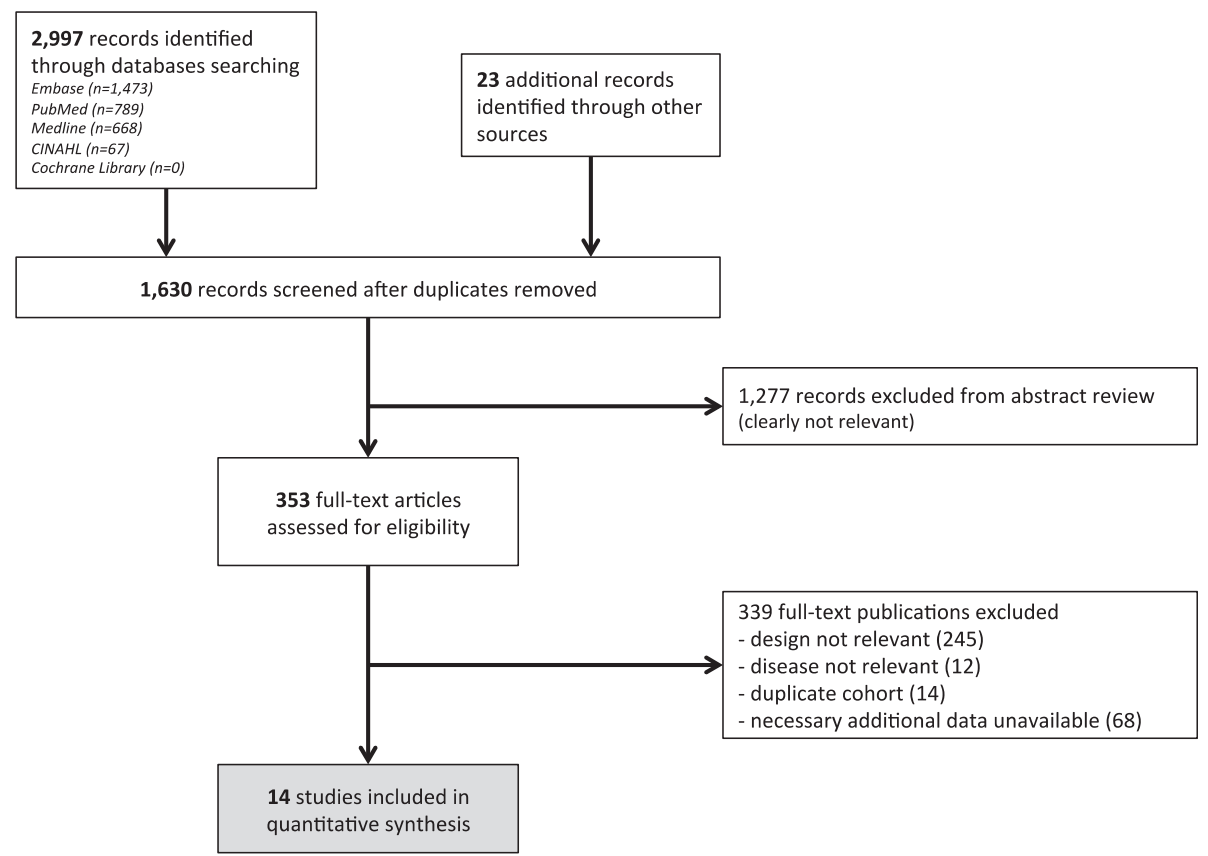

Fig. 1 Flow chart of the selection process

were eligible because none of them monitored HIV incidence and STI status at least monthly (our threshold to ascertain concomitance). Hence our findings are limited to an indirect measurement of HIV-infectiousness as measured by viral load at various anatomical sites. Of these 14 studies, two studies included participants from resourcelimited countries [31, 34]; four studies focused on MSM [35-38]; and two reported on ART adherence [34, 40]. Syphilis, chlamydia and gonorrhea were the most reported STIs in the eligible studies. We provide further detail on the STI co-infections tested for and the anatomical sites sampled by each study in the Additional file 6 .

Three studies included in this review [31, 33, 40] did not focus on differences in HIV infectiousness between STI co-infected and HIV mono-infected groups as a primary outcome. Among the 11 other studies, 7 suggest that co-infection with another genital infection may be associated with an increase in HIV viral load [10, 26, 35-39].

Table 2 outlines the main features from studies that could bias our estimates. The more STIs tested, the smaller the risk of incorrectly categorizing individuals as monoinfected. Six studies [32-34, 37, 39, 40] out of 14 reported on testing more than 4 STIs (in addition to HIV). Reporting adherence to ART reduces statistical misattribution of the reasons for increases in HIV viral load. Three studies $[20,34,41]$ out of 14 explicitly reported adherence to ART. Because of HIV compartmentalization [42] (viral concentration may substantially differ between different anatomical sites within the same individual at a given time), measuring HIV viral load in genital or anal secretions is most relevant when considering sexual transmission. Eight out of 14 studies measured HIV viral load in such anatomical sites [10, 12, 26, 32, 34, 37-39].

\section{Meta-analysis}

The 14 studies included in the meta-analysis represent 4607 visits from 2835 unique individuals (Table 3). The posterior distributions of effect sizes for each study, averaged across the associated STIs and anatomical sites, are shown in Fig. 2. We estimated that, among HIV-infected individuals on ART, the presence of another STI coinfection was associated with an HIV viral load $0.11 \log 10$ (95\% CI -0.62 to 0.83 ) higher than in HIV mono-infected individuals, averaging over both anatomical sites and different STIs. Thus, we did not find a statistically significant effect of STI co-infection on the viral load of HIV-infected individuals on ART. Similarly, we did not find any statistically significant effect of STI co-infections on viral load when examining the effect on viral load as measured at a particular anatomical site, or for a particular STI coinfection, although we note that most of the posterior distributions for the effects of co-infection on viral load had positive means (Fig. 3).

Figure 4 shows a funnel plot of included studies and doesn't exhibit a strong asymmetry, hence suggests no obvious publication bias. Another risk of bias across studies could have been introduced if temporal changes in STI prevalence and ART regimens were not adequately captured by the model. 


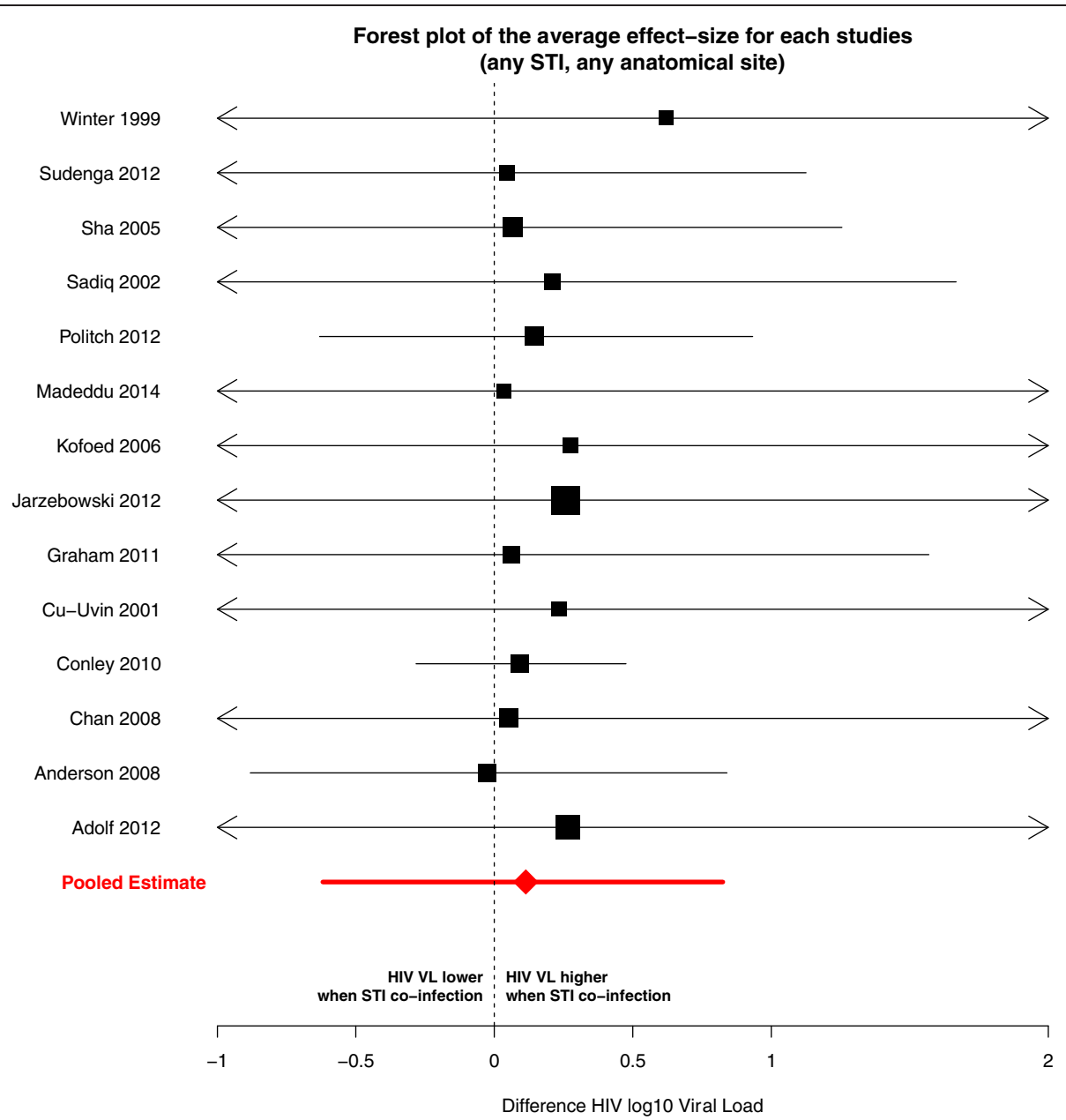

Fig. 2 Posterior means and $95 \%$ credible intervals of the effect size for each study included in the meta-analysis. The effect size is expressed as the difference of HIV viral load (log10) between an individual HIV positive, co-infected with any other STI and an individual only infected with HIV. The black square represents the posterior mean, with its area proportional to study sample size. The red diamond and arrows reflect estimates of the pooled effect (i.e., across all studies, STIs and anatomical sites)

The impact of heterogeneity between studies on the summary effect size (using the $\mathrm{I}^{2}$ statistic [43]) could not be reliably captured because of the large variance associated with our estimates (see Additional file 5). Three studies $[31,39,40]$ exhibited HIV viral loads indicative of incomplete viral suppression in a non-negligible proportion of participants (i.e. HIV viral load above $4 \log 10$ ). We did a sensitivity excluding these studies and did not find any qualitative differences in our results (see Additional file 7).

Visits where patients were co-infected with two or more STIs other than HIV (381 out of 4219 total visits) were not used in the main analysis because our model structure specified unique effects for each type of STI co-infection; we used a sensitivity analysis to explore the effects of this exclusion and found no qualitative impact on our results (see Additional file 7).

\section{Discussion}

In the absence of qualifying studies that measured transmission risk directly, we conducted a meta-analysis of all available evidence of increased HIV viral load due to STI co-infection of individuals on ART, as a proxy for increased infection risk. Pooling information from all available studies, anatomical sites, and co-infections, we estimated that the average difference in viral load due to STI co-infection of individuals on ART was $0.11 \log 10$ (95 \% CI -0.62 to 0.83 ) greater than HIV mono-infected individuals.

Although our study provides some evidence for a small effect of STI co-infection on viral loads, we cannot rule out the possibility of no effect, or the possibility of a moderately large effect (the upper credible interval is 0.83 $\log 10)$. Importantly, we are also not able to rule out the 


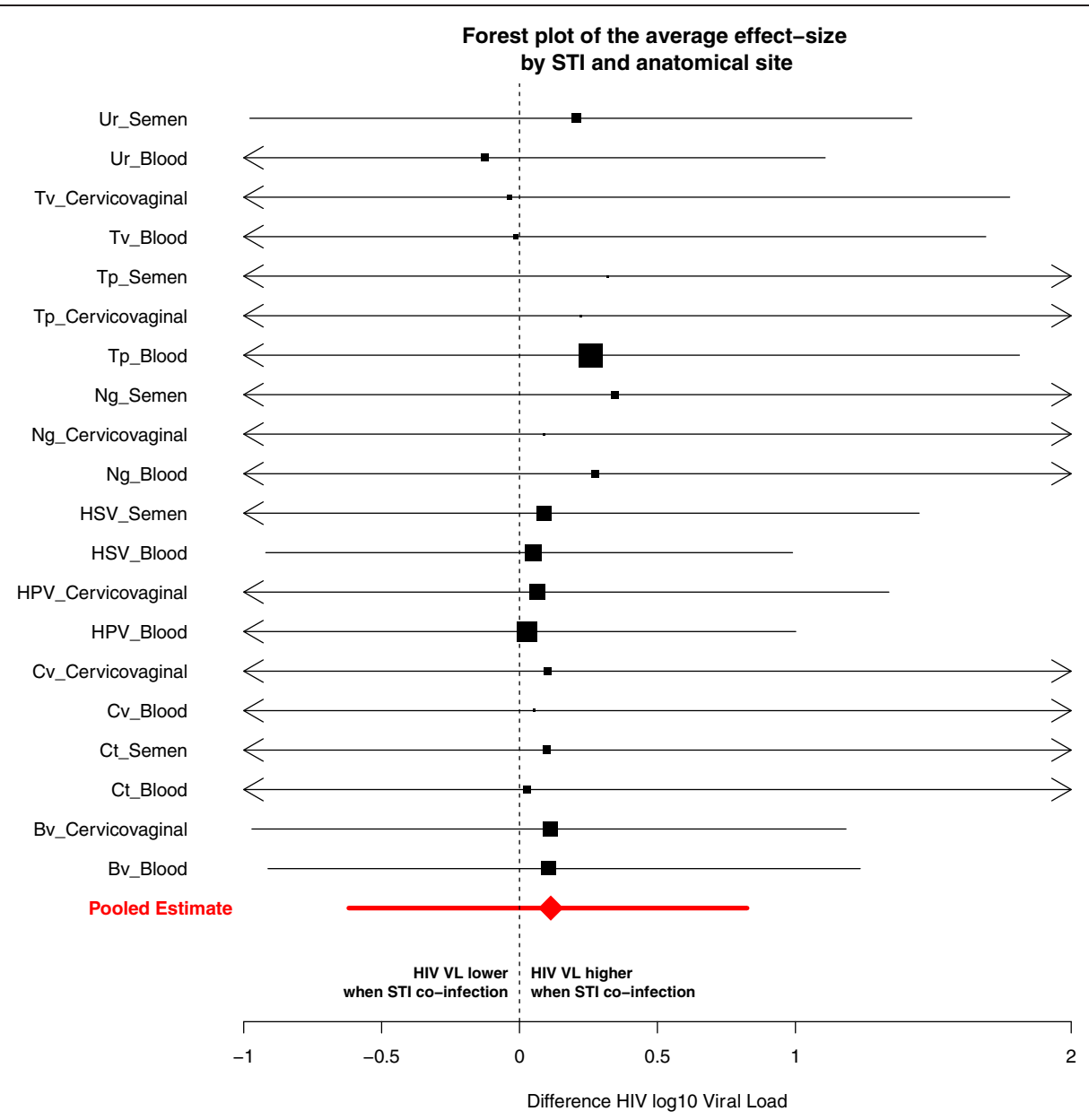

Fig. 3 Forest plot for a given STI/anatomical site pair. Posterior means and $95 \%$ credible intervals of the effect size for each study included in the meta-analysis. The effect size is expressed as the difference of HIV viral load (log10) between an individual HIV positive, co-infected with an STI and an individual only infected with HIV. The black square represents the mean of the distribution, its area is proportional to the number of data points associated with the specific STI/anatomical site pair; segments represent the $95 \%$ credible intervals (CI). The red diamond shows the mean of the pooled effect (across all studies, STIs and anatomical sites) and the segment its $95 \% \mathrm{Cl}$. Bv: Bacterial vaginosis; Ct: Chlamydia trachomatis; Cv: Candidal vaginitis; Bacterial vaginosis; HPV: human papillomavirus; HSV: human simplex virus type 2; Ng: Neisseria gonorrhoeae; Tp: Treponema pallidum; Tv: Trichomonas vaginalis; Ur: urethritis

possibility that certain STIs (or certain combinations of STIs and anatomical site) have a much larger effect (see Fig. 3). Nonetheless, based on our analysis, we cautiously posit that ART manages-on average-to sustain its effectiveness at keeping HIV viral loads low during STI coinfection episodes, at the anatomical sites considered in this review (blood plasma, semen and cervicovaginal), and thus would be expected to maintain its effectiveness at preventing transmission.

Even with nearly 5000 data points used in this metaanalysis, realistic consideration of the variation between studies, STIs and anatomical sites reduces the statistical power considerably. There are other limitations that need to be highlighted.

Because eligible studies only estimated HIV viral loads, not transmission rates in discordant couples, our summary effect size is a proxy for HIV infectiousness and might not be an accurate representation of the actual sexual transmission risk. There were no eligible studies measuring rectal HIV viral load, so our estimate may not be applicable in assessing change in HIV infectiousness from receptive anal intercourse.

Not all studies tested for all STIs, hence we may have misclassified some co-infected individuals. This misclassification is likely, given the high prevalence rate of other STIs in the HIV-infected population [17]. Such misclassification could bias our estimates of the effect of STI on HIV viral load downwards.

Our study focused on whether STIs could interfere with viral suppression, and we therefore excluded HIV VL measurement done within 30 days of ART initiation. It seems likely that the effects of STIs on HIV viral load 


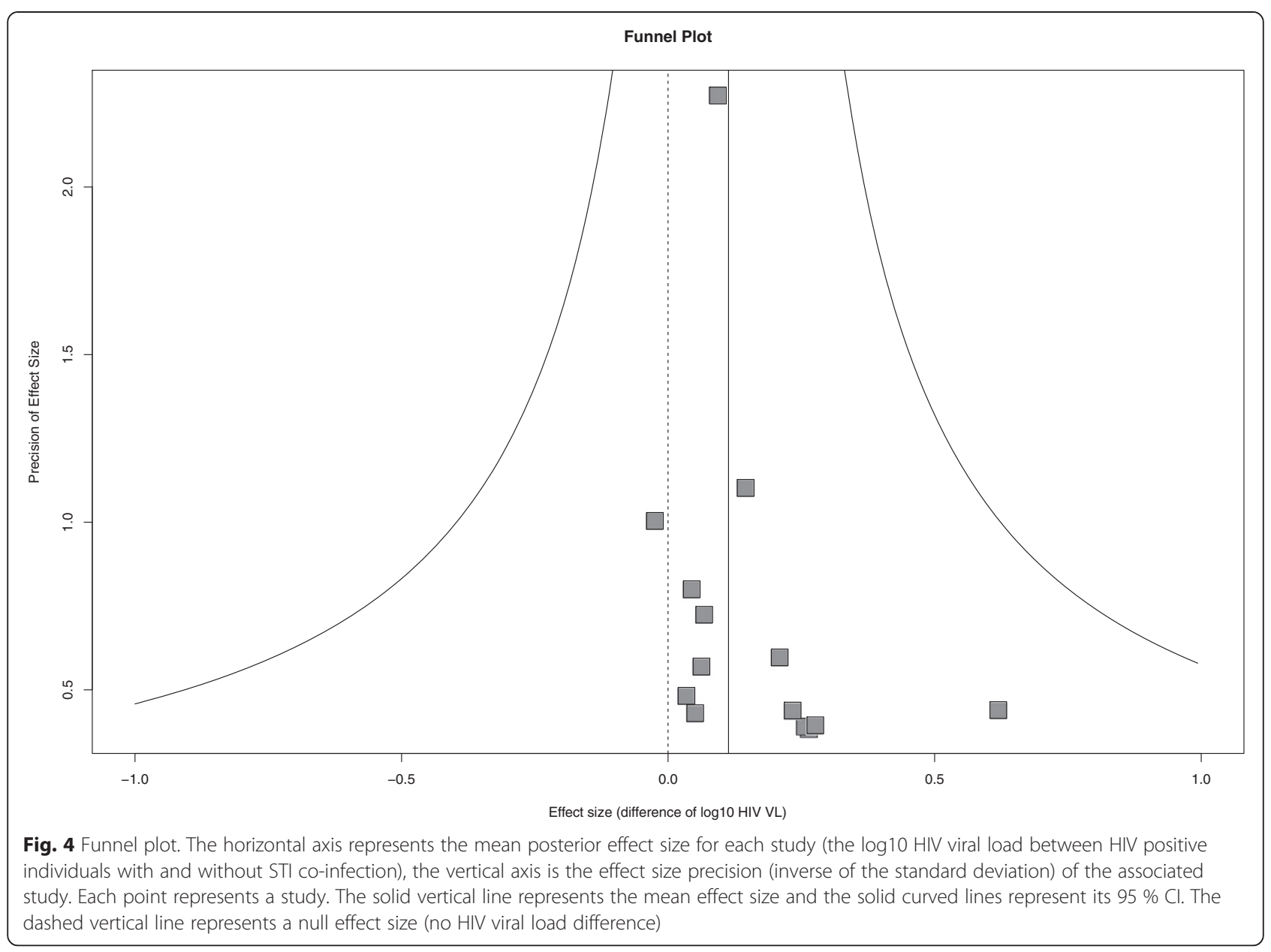

early in treatment are comparable to the effects before treatment begins and decline gradually through time, in an STI-specific fashion. We did not find any studies that could provide evidence bearing directly on the effect of STIs when ART has been initiated recently.

Adherence to ART was rarely reported or measured in the studies we used. Since the effect of STI co-infection on viral load would be stronger in people with poorly controlled viral loads, this effect is likely to bias our result. This bias will be exacerbated if co-infected individuals exhibit lower adherence (or could be reduced, or even reversed, if they are more likely to adhere, perhaps due to symptoms from the other STIs).

Most HIV viral load observations included in this metaanalysis were measured in blood plasma, not in genital secretions, which may limit the interpretation of our effect size to actual sexual transmission risk. Indeed, while plasma and genital HIV viral loads are correlated [44], evidences of HIV compartmentalization in some treated patients where viral loads as measured in genital secretions remain compatible with a non-negligible risk of transmission despite very low blood plasma viral loads $[37,45,46]$.
We did not estimate gender-specific effects to avoid further complicating our model. It is possible that gender confounds our results to some extent. We note, however, that such confounding would be limited to blood measurements, since gender is implicitly accounted for in the other anatomical sites studied. Also, our estimate did not include a potential effect of menstrual cycle on genital HIV viral load, but we note that a recent study did not observe such effect [47].

If STIs were indeed an escape route for treatment as prevention, one could argue this should have shown up during large trials studying transmission rate among HIV discordant couples (for example [5]). But such trials do not provide complete reassurance, since trial participants are given STI monitoring and treatment not available to the general population.

The number of HIV-infected individuals receiving ART has dramatically increased during the last 10 years-from less than half a million in 2003 to about 13 million in 2013-and will increase further [18, 48]. The extended life expectancy associated with ART and the potentially higher exposure to STIs of the HIV-infected population may 
increase the prevalence of STI co-infections, particularly with public awareness of the decreased infectiousness of HIV while on ART and a potentially consequential decrease in condom usage. Hence, understanding the effects of such co-infections on HIV sexual transmission is an important public health issue.

Our study provides some insights into whether STI co-infections can undercut treatment as prevention efforts. Pooling available data, we estimate the degree to which STI co-infection may increase or decrease HIV shedding among treated individuals. We found a $95 \%$ upper bound corresponding to a $0.83 \log 10$ increase, which suggests that elevation of viral load by STI coinfections is unlikely to have a major impact on the ability of ART to reduce of HIV sexual transmission from patients on effective ART (as opposed to what could be observed in populations not on ART).

It is important to note that our results do not undercut the importance of control and treatment of STIs, not only for the well-being of infected individuals, but also for reducing HIV sexual transmission at the whole population level, which still has a majority of HIV infected individuals not on effective ART [18].

We did not have sufficient data to single out the effect of a specific STI on HIV viral load at a given anatomical site. Given the heterogeneous effect of STIs on HIV infectiousness, our analysis may have failed to identify epidemiologically relevant effects of particular STIs.

Hence, an important finding of our systematic review is that there is a paucity of available data with a sufficient level of detail to ascertain the effects of STI co-infection on the risk of HIV sexual transmission risk for individuals on ART. Future studies considering either transmission rate or HIV viral load may wish to consider the following suggestions: (i) given the possible high prevalence of co-infections among HIV-infected individuals, a broadest spectrum of relevant STIs should be tested; for transmission studies, testing should be performed frequently in both partners; (ii) HIV viral load should be measured in genital/rectal secretions, not blood plasma only; (iii) ART regimens and adherence should be reported, ideally at the patient level. We recognize that these suggestions may not always be practical, but when they can be followed they will help clarify the potentially important effects of STIcoinfection on the risk of HIV sexual transmission.

\section{Conclusions}

Our findings suggest that, on average, ART maintains its effectiveness at controlling HIV viral load during STI co-infections. However, with currently available data, we cannot rule out the possibility that certain STI co-infections have a larger effect. More high-quality studies specifically aimed at investigating the impact of STI co-infection on HIV sexual transmission from individuals on ART are needed.

\section{Additional files}

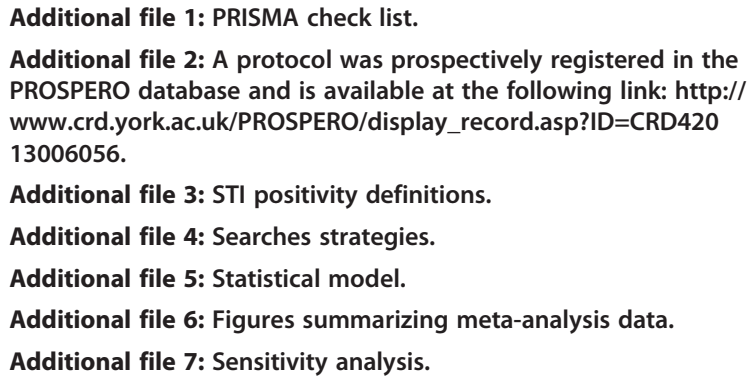

\section{Competing interests}

The authors declare that they have no competing interests.

\section{Authors' contributions}

Conceived the study: DC and JD. Designed the study: DC, JD, SB, WD, MS. Searched the scientific literature: DC, CFS, SH. Statistical analysis: DC and JD. Drafted the report: DC and JD. Interpretation, revisions to the draft report and approval of final manuscript: all co-authors.

\section{Acknowledgments}

We are very grateful to the original investigators who spent time and efforts to retrieve additional data that greatly improved the quality of this meta-analysis and particularly to Sophie Grabar, Joseph Politch, Colleen Kelley, Allison Delong, John T Brooks, Lois Conley, Tim Bush, Rafael Adolf, Ruth Deya, Kaveh Manavi, Susan Graham, Andrea Low, Kate Buchacz, Beverly Sha, Kristian Kofoed. We would also like to thank the librarians at the Health and Science Library in McMaster University for their help with the search strategies; Ben Bolker and Steve Walker for statistical advices.

\section{Funding}

James S. McDonnell Foundation, the Canadian Institutes of Health Research the Canadian Natural Sciences and Engineering Research Council, National Institute of General Medical Sciences (Models of Infectious Disease Agent Study).

\section{Author details}

${ }^{1}$ McMaster University, Hamilton, ON, Canada. ${ }^{2}$ The University of Texas at Austin, Center for Computational Biology and Bioinformatics, Austin, TX, USA. ${ }^{3}$ The South African DST/NRF Centre of Excellence in Epidemiological Modelling and Analysis (SACEMA), University of Stellenbosch, Stellenbosch, South Africa. ${ }^{4}$ International Centre for Reproductive Health (ICRH), Ghent University, Ghent, Belgium.

Received: 11 December 2014 Accepted: 21 May 2015

Published online: 30 June 2015

\section{References}

1. Baggaley RF, White RG, Hollingsworth TD, Boily M-C. Heterosexual HIV-1 infectiousness and antiretroviral Use:systematic review of prospective studies of discordant couples. Epidemiology. 2013;24:110-21.

2. Loutfy MR, Wu W, Letchumanan M, et al. Systematic review of HIV transmission between heterosexual serodiscordant couples where the HIV-positive partner is fully suppressed on antiretroviral therapy. PLoS One. 2013;8, e55747.

3. Attia S, Egger M, Müller M, Zwahlen M, Low N. Sexual transmission of HIV according to viral load and antiretroviral therapy: systematic review and meta-analysis. AIDS. 2009;23:1397-404.

4. Reynolds SJ, Makumbi F, Nakigozi G, et al. HIV-1 transmission among HIV-1 discordant couples before and after the introduction of antiretroviral therapy. AIDS. 2011;25:473-7.

5. Cohen MS, Chen YQ, McCauley M, et al. Prevention of HIV-1 infection with early antiretroviral therapy. N Engl J Med. 2011;365:493-505.

6. Anglemyer A, Rutherford GW, Horvath T, Baggaley RC, Egger M, Siegfried N. Antiretroviral therapy for prevention of HIV transmission in HIV-discordant couples (Review). In: The Cochrane Collaboration. 2012. p. 1-57. 
7. Granich RM, Gilks CF, Dye C, De Cock KM, Williams BG. Universal voluntary HIV testing with immediate antiretroviral therapy as a strategy for elimination of HIV transmission: a mathematical model. Lancet. 2009;373:48-57.

8. Vernazza PL, Hirschelb B, Bernasconic E, Fleppd M. Les personnes séropositives ne souffrant d'aucune autre MST et suivant un traitement antirétroviral efficace ne transmettent pas le VIH par voie sexuelle. Bulletin des médecins suisses| Schweizerische Ärztezeitung| Bollettino dei medici svizzeri. 2008;89:5.

9. Johnson LF, Lewis DA. The effect of genital tract infections on HIV-1 shedding in the genital tract: a systematic review and meta-analysis. Sex Transm Dis. 2008;35:946-59.

10. Winter AJ, Taylor S, Workman J, et al. Asymptomatic urethritis and detection of HIV-1 RNA in seminal plasma. Genitourin Med. 1999;75:261-3.

11. Røttingen J-A, Cameron DW, Garnett GP. A systematic review of the epidemiologic interactions between classic sexually transmitted diseases and HIV: how much really is known? Sex Transm Dis. 2001;28:579-97.

12. Chan DJ, McNally L, Batterham M, Smith DE. Relationship between HIV-RNA load in blood and semen in antiretroviral-naïve and experienced men and effect of asymptomatic sexually transmissible infections. Curr HIV Res. 2008;6:138-42.

13. Boily M-C, Baggaley RF, Wang L, et al. Heterosexual risk of HIV-1 infection per sexual act: systematic review and meta-analysis of observational studies. Lancet Infect Dis. 2009;9:118-29.

14. Rotchford K, Strum WA, Wilkinson D. Effect of coinfection with STDs and of STD treatment on HIV shedding in genital-tract secretions: systematic review and data synthesis. Sex Transm Dis. 2000;27:243-8.

15. Naresh A, Beigi R, Woc-Colburn L, Salata RA. The bidirectional interactions of human immunodeficiency virus-1 and sexually transmitted infections: a review. Infect Dis Clin Pract. 2009;17:362-73.

16. Galvin SR, Cohen MS. The role of sexually transmitted diseases in HIV transmission. Nat Rev Micro. 2004;2:33-42.

17. Kalichman SC, Pellowski J, Turner C. Prevalence of sexually transmitted coinfections in people living with HIV/AIDS: systematic review with implications for using HIV treatments for prevention. Sex Transm Infect. 2011;87:183-90.

18. The GAP report. Geneva: UNAIDS; 2014.

19. Taylor S, Davies S. Antiretroviral drug concentrations in the male and female genital tract: implications for the sexual transmission of HIV. Curr Opin HIV AIDS. 2010;5:335-43.

20. Anderson BL, Cu-Uvin S. Determinants of HIV shedding in the lower genital tract of women. Curr Infect Dis Rep. 2008;10:505-11.

21. Pasquier C, Andreutti C, Bertrand E, et al. Multicenter assessment of HIV-1 RNA quantitation in semen in the CREAThE network. J Med Virol. 2011;84:183-7.

22. Iglesias-Ussel MD, Romerio F. HIV reservoirs: the new frontier. AIDS Rev. 2011;13:13-29.

23. Lee PK. HIV-1 viral load blips are of limited clinical significance. J Antimicrob Chemother. 2006;57:803-5.

24. Moher D, Liberati A, Tetzlaff J, Altman DG. The PRISMA Group (2009) Preferred Reporting Items for Systematic Reviews and Meta-Analyses: The PRISMA Statement. PLoS Med 6(7): e1000097. doi:10.1371/journal.pmed. 1000097

25. Sutton AJ, Abrams KR. Bayesian methods in meta-analysis and evidence synthesis. Stat Methods Med Res. 2001;10:277-303.

26. Cu-Uvin S, Hogan JW, Caliendo AM, Harwell J, Mayer KH, Carpenter CC. Association between bacterial vaginosis and expression of human immunodeficiency virus type 1 RNA in the female genital tract. Clin Infect Dis. 2001;33:894-6.

27. Dominici F, Parmigiani G. Combining studies with continuous and dichotomous responses: a latent-variables approach. In: Stangl DK, Berry DA, editors. Meta-analysis in medicine and health policy. New-York: Marcel Dekker; 2000.

28. Gelman A, Carlin JB, Stern HS, Dunson DB, Vehtari A, Rubin DB. Bayesian data analysis, Third Edition. Boca Raton, Florida: CRC Press; 2013.

29. R Core Team. R: a language and environment for statistical computing. $R$ Foundation for Statistical Computing. http://www.R-project.org/.

30. Stan Development Team. Stan: A C++ library for probability and sampling, version 2.2. 2014. http://mc-stan.org/.

31. Adolf R, Bercht F, Aronis ML, Lunardi LW, Schechter M, Sprinz E. Prevalence and risk factors associated with syphilis in a cohort of HIV positive individuals in Brazil. AIDS Care. 2011;24:(2)1-7.

32. Anderson BL, Wang CC, DeLong AK, et al. Genital tract leukocytes and shedding of genital HIV Type 1 RNA. Clin Infect Dis. 2008;47:1216-21.
33. Conley L, Bush T, Darragh TM, et al. Factors associated with prevalent abnormal anal cytology in a large cohort of HIV-infected adults in the United States. J Infect Dis. 2010;202:1567-76.

34. Graham SM, Masese L, Gitau R, et al. Genital ulceration does not increase HIV-1 shedding in cervical or vaginal secretions of women taking antiretroviral therapy. Sex Transm Infect. 2011;87:114-7.

35. Jarzebowski W. Effect of early syphilis infection on plasma viral load and CD4 cell count in human immunodeficiency virus-Infected men. Arch Intern Med. 2012;172:1237.

36. Kofoed K, Gerstoft J, Mathiesen LR, Benfield T. Syphilis and Human Immunodeficiency Virus (HIV)-1 Coinfection: influence on CD4 T-cell count, HIV-1 viral load, and treatment response. Sex Transm Dis. 2006;33:143-8.

37. Politch JA, Mayer KH, Welles SL, et al. Highly active antiretroviral therapy does not completely suppress HIV in semen of sexually active HIV-infected men who have sex with men. AIDS. 2012;26:1535-43.

38. Sadiq ST, Taylor S, Kaye S, et al. The effects of antiretroviral therapy on HIV-1 RNA loads in seminal plasma in HIV-positive patients with and without urethritis. AIDS. 2002;16:219-25.

39. Sha BE, Zariffard MR, Wang QJ, et al. Female genital-tract HIV load correlates inversely with Lactobacillus species but positively with bacterial vaginosis and Mycoplasma hominis. J Infect Dis. 2005;191:25-32.

40. Sudenga SL, Kempf M-C, McGwin Jr G, Wilson CM, Hook III EW, Shrestha S. Incidence, prevalence, and epidemiology of herpes simplex virus-2 in HIV-1Positive and HIV-1-Negative adolescents. Sex Transm Dis. 2012;39:300-5.

41. Madeddu G, Mameli G, Capobianco G, et al. HPV infection in HIV-positive females: the need for cervical cancer screening including HPV-DNA detection despite successful HAART. Eur Rev Med Pharmacol Sci. 2014;18:1277-85.

42. T Blackard J. HIV compartmentalization: a review on a clinically important phenomenon. Curr HIV Res. 2012;10:133-42.

43. Higgins JPT, Thompson SG. Quantifying heterogeneity in a meta-analysis. Stat Med. 2002;21:1539-58.

44. Baeten JM, Kahle EM, et al. Genital HIV-1 RNA predicts risk of heterosexual HIV-1 transmission. Sci Transl Med. 2011;3:77ra29-9.

45. Lambert-Niclot S, Tubiana R, Beaudoux C, et al. Detection of HIV-1 RNA in seminal plasma samples from treated patients with undetectable HIV-1 RNA in blood plasma on a 2002-2011 survey. AIDS. 2012;26:971-5.

46. Graham SM, Holte SE, Peshu NM, et al. Initiation of antiretroviral therapy leads to a rapid decline in cervical and vaginal HIV-1 shedding. AIDS. 2007;21:501-7.

47. Sheth AN, Evans-Strickfaden T, Haaland R, et al. HIV-1 genital shedding is suppressed in the setting of high genital antiretroviral drug concentrations throughout the menstrual cycle. J Infect Dis. 2014;210:736-44.

48. UNAIDS. Treatment 2015. UNAIDS report. 2013. p. 1-44.

\section{Submit your next manuscript to BioMed Central and take full advantage of:}

- Convenient online submission

- Thorough peer review

- No space constraints or color figure charges

- Immediate publication on acceptance

- Inclusion in PubMed, CAS, Scopus and Google Scholar

- Research which is freely available for redistribution 